\title{
The History of the First Siberian Art Societies Development (1905-1932)
}

\author{
Liliya Stroy \\ Krasnoyarsk State Institute of Arts \\ Krasnoyarsk, Russia \\ E-mail: Listroy@yandex.ru
}

\begin{abstract}
Using the archival documents and historical media the article reconstructs the history of the 20th century Siberian art societies and analyses their influence on the cultural life of the region. Such processes as generating the art language, organizing art education and exhibitions promoted uniting the local artists and shaping the "Siberian style" as far as organizing the Soviet Artists' Union.
\end{abstract}

Keywords-artist; art life; art society; artists' union; art exhibition; Siberian style; "Novaya Sibir" (New Siberia); creative processes

\section{INTRODUCTION}

In late $19^{\text {th }} \sim$ early $20^{\text {th }}$ centuries, the core elements of the home art were art societies ready to consolidate creative forces standing in the centre of the country's social and political life. The groups' activity, their social positioning and public awareness campaigns influenced the creative environment of the Russian cities, determined the population's cultural level, and formed public opinions. The history of developing Siberian art societies dating back to the early $20^{\text {th }}$ century is a subject matter for Russian art historians' research. The work by P. D. Muratov, "Siberian Art Life in the 1920s" (1974), is still significant. There is such a fundamental research as the work by D. Ya. Severyukhin and O. L. Leikind, "The Golden Age of Art Unions in Russia and USSR (1820-1932)" (1992). Another important study significant for this article is that by $\mathrm{Zh}$. Ye. Levina, "Art Intellectuals of West Siberia (late 1920-1930s)" (2007). A considerable contribution to studying the regional art life was the two-volume glossary, "Siberian Visual Arts in the $17^{\text {th }}-20^{\text {th }}$ Centuries" (2014), by V. F. Chirkov. Thanks to extensive research work not only can scholars reconstruct the provincial art history but they also redefine the conventional judgement of the local art societies' development and their contribution to the culture of the region and the whole Russia.

The first Russian public organization founded by art patrons supporting fine arts development was the St Petersburg Society for Encouragement of Artists (18201932). In 1860 Moscow intellectuals and professionals founded the Moscow Society of Art Lovers, in 1863 the St Petersburg Artists' Artel (association) was organized. In the 1860 s young provincial artists learning in the capitals were actively involved into the integrational process. It was at that time when the St Petersburg students representing Siberian community started developing and spreading the ideas of separatism, the Siberian political, economic and cultural autonomy. Their programme called Siberian localism attracted the authorities' attention and in 1865 the group members were arrested. After their punishment endured, the localists continued spreading their ideas in the region and won loyal supporters and followers including the artists.

\section{THE TOMSK SOCIETY OF ART LOVERS}

In 1902, Grigory Nikolaevich Potanin, one of the localist leaders, made Tomsk his home. He immediately plunged into the city's art life which was prospering thanks to opening of the first Siberian university (1888). The professors and creative elite of the country who had come from Central Russia to teach the local young people influenced the character and level of the cultural processes in Tomsk. Soon the city's art events stepped out its boundaries and spread as far as Krasnoyarsk, Irkutsk, Barnaul, which promoted the creative unity of the region. That process was fostered with railway construction and organizing the Tomsk Society of Art Lovers (TOLKh) which was active from 1909 to 1919 .

The TOLKh members promoted organizing the local "...close-knit circle of people who could raise the vital spirit and influence it" [1]. G. N. Potanin, L. P. Bazanova, A. S. Kapustina, M. M. Shcheglov, A. V. Adrianov and other representatives of the association organized exhibitions, got in contact with the regional artists and educated the population actively propagating the role of art in the local mass media. In 1913, Adrianov noted that "first and foremost, the society united a considerable group of artists with common objectives spread all over Siberia. In Tomsk they had a kind of centre keeping the light of art life. Organizing annual art exhibitions in Tomsk and sometimes in other cities, the society not only consolidated the local srtists as a family, but also raised the level of understanding art by the local community" [2].

One of the TOLKh charter objectives was to organize an art and design school. The number of applicants proved the importance of the initiative. Instead of the planned 36 students, the Tomsk art classes opened in 1910 accepted 50 people. In spite of consistent problems with staff and finance, lack of permanent premises, tough relations with the TOLKh 
members, the school was engaged in art education. In May 1918, the school shortly worked as Siberian people's academy, but soon it was closed because of revolutionary events.

At that historical stage, the formation of the local art education system was interrupted, as well as developing the idea of "Siberian art style" which was conceived by the TOLKh members in the 1910s. The Society sessions used to discuss the works created within the style by the following artists: N. P. Tkachenko, N. I. Molotilov, M. M. Shcheglov, the architect T. L. Fishel, who used the northern decorative designs for furniture [3]. The "Siberian art style" was the theme of the talk given by the Tomsk ethnographer and enlightener, A. V. Adrianov, a TOLKh member, at the AllRussia Congress of Artists (St Petersburg, 1912). He explained to the delegates who had come from all corners of Russia that "the rhythmics and colour structure of Siberian people's designs were to become the starting point of searching the local identity for Siberian artists" [4].

The idea corresponded with the localists' ideas supporting the regional unity through artistic devices. However, "the first experiments did not give the style itself, but only a stylized design $\langle\ldots\rangle$, an eclectic mixture of Siberian types and ornamental sketches drawn from nature. Most works of "Siberian style" were ethnographic sketches sometimes made at a very high academic level (sic!)" [5]. A significant role in the processes belonged to the local artists. Some of them took part in research expeditions.

\section{THE FIRST ASSOCIATIONS OF KRASNOYARSK ARTISTS}

The Krasnoyarsk painter Dmitry Ivanovich Karatanov showed interest in local art studies in his youth. He was greatly impressed with Ivan Timofeevich Savenkov, the director of Krasnoyarsk real school who came back from archeological expedition to the upper reaches of the Yenisei and showed him "interesting drawings and water colours copied from prehistoric sketches and inscriptions abundant on the painted rocks along the river" [6]. In 1906, Karatanov made his first trip to Turukhansk territory to study the art and ethnography of Siberia. There were also many other expeditions which allowed the artist to depict the unique Siberian world with the language of arts. The painter pointed out that "Siberia lived with its own life, very different from that of European Russia. Its vast spaces, its more severe climate, its isolation from the metropolitan country" [7] created the individual character of the country's East, and the artists tried to praise it through the "Siberian style". That desire united the regional artists and promoted organizing art societies in different cities including Krasnoyarsk.

In 1905 the Krasnoyarsk artists D. Karatanov, A. Shestakov, M. Kostylev, G. Kozlov, P. Vladimirov informed the Yenisei Province government about consolidating "the art forces for developing and promoting fine arts in the community. In view of this, the society opens painting and drawing classes and organizes exhibitions from time to time. Taking care of material resources the society undertakes various art works, such as portraits, paintings, set designs etc., it also organizes performances, concerts, parties etc.' [8]. The initiator of organizing the society could have been the painter Andrei Sergeevich Shestakov who had graduated from Moscow School of Painting, Sculpture and Architecture (MSPSA). Working in Munich and the cities of Central Russia, Andrei Sergeevich could see artists' participation in numerous cooperatives. Such an experience proved that consolidated art forces could reach good results in promoting their own creative initiatives and had higher social status. Trying to organize something similar in their native city, they decided to start with the local art school. In 1905, the association opened drawing and painting classes that later came across continuous financial and technical problems. In two years, the art school was closed, and the Society finished its work [9]

The question of professional consolidation of the city artists arose in 1916, when the First Siberian exhibition of paintings and sculpture by Siberian artists took place (February $23 \sim$ March 7). The exposition was organized by the Krasnoyarsk section of the Siberian Society of Aid to Sick and Wounded Warriors. Supported by Yeniseisk Governor, the society presented 276 works by 18 regional authors on condition that five per cent of the funds raised would be transferred to the warriors' needs [10]. The exhibition attracted the citizens' attention and "grounded the Siberian artists' consolidation as well as founding the artists' society in Krasnoyarsk" [11].

It happened in December 1917: D. I. Karatanov, A. F Yefremov, A. S. Sergeyev, V. G. Vagner, K. G. Polyakov, V. U. Ignatovich, P. K. Patrushev tried to get the Krasnoyarsk artists' society registered in the district court. The artists presented their organization charter; their objective being "association of the people working independently in the field of arts" [12]. Though the registration was not granted, supposedly because of the regulations not answering the legal demands [13], a year later the local media published information on the Yenisei Union of artists and applied art workers, under the chairmanship of D. I. Karatanov. The association's efforts were aimed at organizing exhibitions and supporting the art school founded in Krasnoyarsk in 1910. In 1918 the drawing classes where 45 children studied [14], were in distressful situation. The teachers who were the society members asked the city authorities for help [15]. They did not get any support, so they decided to save the school with exposition fundraising. In April 1919 the artists held the spring travelling display [16], in September they started preparing the autumn exposition. However, all the attempts to save the school did not lead to the desired results, and in December the general assembly of the Yenisei Union of artists and applied art workers decided to close the school [17].

In 1920 the society was a communal studio where not only Krasnoyarsk artists could attend, but also "the newcomers who had settled in the city" [18], i.e. the WWI prisoners. A military quarter was built in the city especially for them; Germans, Austrians, Turks, Poles, Hungarians, Italians, Romanians having nothing for a living could survive there using their pre-war knowledge and skills. They organized orchestras, staged performances and founded 
"craft teams <..>. When those Austrian craftsmen and farmers wearing their thin boots with leggings, poor coats and caps crouched in freezing cold in the foreign country, unnecessary for them, and tried to earn a living with their work, the Krasnoyarsk people's hearts used to flutter with grief and sympathy for those innocent suffering people and with indignance for those who had thrown them into unhappiness" [19]. Until 1918 the war prisoners were allowed to move freely around the city and the foreign artists could come to the former photographic studio, the glass house where the local artists used to gather. In 1920s Krasnoyarsk counted about 70 prisoner artists, they were drawing artists, landscapists, and easel painters. They introduced their own traditions into the local art, and "organized their own exhibitions in Krasnoyarsk. <..> There were also Russian artists thrown to Krasnoyarsk by the war" [20]. One of such masters was a professional drawing artist, Ivan Ivanovich Lyakhov.

Lyakhov had served in Kolchak army and survived in German captivity [21]. In 1920s he ended up in Krasnoyarsk [22], and in 1926 he joined the board of the Krasnoyarsk art group, together with the artists V. L. Petrakov and P. N. Pakshin. The group's objective was to fight against trash art, to promote the artists' professional development and to educate the citizens [23]. The group organized exhibitions in the city and supported the Novosibirsk artists' idea to organize the regional "Novaya Sibir" (New Siberia) society. Soon I. I. Lyakhov headed the Krasnoyarsk branch of the society.

\section{ThE "Novaya SibIR" (New Siberia) ART SocIETy}

The Novosibirsk "Novaya Sibir" society was initiated in 1926 by Aleksey Vasilievich Voshchakin, a disciple of D. I. Karatanov [24]. Together with 14 fellow thinkers he called the artists to march under the red banner, in step with the proletarian revolution, celebrating its achievements and courageously overcoming all the difficulties. The organization set an objective of making All-Siberian exhibitions at least once a year, so they called all Siberian art forces to unite. The idea was a phenomenal success: in 1926 the Tomsk "Novaya Sibir" branch was organized (headed by V. M. Mizerov), then individual artists from Novosibirsk, Irkutsk, Krasnoyarsk, Tomsk, Barnaul, Biysk, Minusinsk joined the society. The artists of Buryatia and Omsk were also expected to join in [25]. In 1927 the "Novaya Sibir" branches were organized in Krasnoyarsk (headed by I. I. Lyakhov), Omsk (headed by V. P. Trofimov), and Barnaul (headed by V. V. Panovsky, since 1928 by A. N. Borisov) [26]. The Irkutsk branch was founded in 1928 (headed by I. L. Kopylov).

In January 1927 the "Novaya Sibir" society united 108 artists, 37 of them became delegates of the First Siberian congress of artists, 75 participated in the First All-Siberian exhibition of painting, sculpture, graphics and architecture. The exposition including 597 works was unveiled in the Novosibirsk regional museum on January 1, 1927. In a fortnight, its two-month travel around the big art centres of Siberia (Omsk, Tomsk, Krasnoyarsk, Irkutsk) with the local artists' works added to the exposition. In spite of D. I.
Karatanov's opinion that there was nothing "Siberian" and little culture in the exposition [27], the people's interest in the large-scale event exceeded all expectations. Private collectors and state offices purchased the works; the event was actively covered in the local media [28]; the exhibition symbolizing consolidation of the Siberian art forces, inspired the artists. Tired of war devastation, revolutionary bloodshed, starvation, lack of commissions, unemployment, public executions and repentance and arrests, they finally felt being in demand.

On the third day of the new 1927 the First Siberian congress of artists started in Novosibirsk. The delegated seated in the city museum, with the sensational exposition on the background, and they discussed the problems of the form and content of Soviet art, they argued about the new type of art lover, the one of mostly workers or peasants' origin; they touched upon the "Siberian style" problem which had been distorted by localists, in Voshchakin's opinion: “They put up the political question - full isolation from Russia, everything Siberian as opposed to it. We do not think of Siberia as separated from the USSR. We have the same objectives, economic and cultural ones" [29]. The main congress debate was on the problem of artists belonging to creative groups and art trends.

The extremes of the Soviet art development in the 1920s were futurism and the AKhRR (the Association of Artists of Revolutionary Russia). The futurists represented the "left", avant-garde wing of art connected with new unconventional art language. Futurism was out of the way of Siberian art; that was the idea expressed in "Art, Artist and Revolution", a speech by A. M. Ivanov, the former chairman of the Novosibirsk AKhRR branch. Though he got his branch included in the "Novaya Sibir", he still supported the AKhRR ideas at the congress, being of the opinion that the association was the only organization reflecting the proletarian aspirations, while realism was the only trend easily comprehensible. Most delegated criticized the speaker: "Comrade Ivanov has badmouthed futurists, thus admitting that he is just ignorant, because it is difficult to deny the significance of futurists even for the methods of elementary art education in our schools" [30].

Still, unlike the Novosibirsk AKhRR members, who had joined Voshchakin's association, or their Tomsk colleagues who had taken part in the congress and exhibition and supported the regional association, the Omsk AKhRR branch demonstrated their uncompromising attitude towards the "Novaya Sibir". The members of the group ignored the congress, while their chairman, Ya. Ya. Yavotin pointed out that only AKhRR could lead the Siberian artists' consolidation. To approve that statement, the Omsk artists increased their membership with the help of exhibitions; they called the First plenary session of the Omsk city artists' federation (1931), they planned to unite the self-taught artists-workers, and they tried to get the state commission [31].

Unlike the Omsk artists, the "Novaya Sibir" strictly rejected the monopoly on the region, they welcomed "free competition in the field of artistic activity both in form and 
in content" [32]. That position was included in the congress resolution. The outcome documents also included decisions on the most urgent problems of art life: promoting exhibitional activity, expanding the regional system of art education, organizing the territorial art council for preserving the cultural heritage and controlling the quality of social art commissioning. However, the problems were not solved: first, because of few opportunities, then because of the Society's dissolution in 1931. The "Novaya Sibir" members were proposed to study the guidelines of the central groups and to get organized as one of their branches [33]. The next year of 1933 was the finishing stage of the multivoiced and multidirectional development of Russian art, and the consolidated Union of Soviet Artists was organized.

\section{CONCLUSION}

In the early 20th century Siberia was going through the same art processes as Central Russia. The regional visual arts history includes: the Altai Art Society (AKhO, 1918-1920); the Altai Art Section attached to Provincial Board of Education (1920-1922); the Barnaul "Khlam" Club of Artists, Writers, Actors and Musicians (1922-1924); the Irkutsk Society of Artists (IOKh, 1914-1923); the Irkutsk "Gagat" Art Group (1920); the Irkutsk "Yurta" Literature and Art Society (1922-1924); the Irkutsk Literature and Art Union (ILKhO, 1923-1926). Besides TOLKh, in the early 20th century in Tomsk there was the Union of Tomsk Artists (1918-1919); the art section ("the Union of 26") as a part of art subdivision in the Tomsk provincial executive committee (1920-1921); the Tomsk AKhRR division (1926-1931).

In the early 20th century Omsk artists organized the Society of Artists and Fine Arts Lovers of the Steppe Territory (OKhLIISK, 1916-1919); the "Drawing Mondays" creative and exhibition union (1916-1917); the "Three of Hearts" literature and art group of young futurists (19211923); the West Siberian Territorial Museum Omsk art group (organized in 1925) and the Omsk AKhRR division (1925-1932). Their Krasnoyarsk colleagues had never tended to unite with All-Russia associations, they worked within the local community: the Krasnoyarsk Artists' Partnership (1905-1907); the Yenisei Union of artists and applied art workers (1918-1919); the communal studio as a part of the Rabis (Art Workers) trade union (around 1920-1922); a group of Krasnoyarsk artists (1926-1929). In 1927 the local masters willingly joined the "Novaya Sibir" Society, which was undoubtedly caused with A. V. Voshchakin belonging to Krasnoyarsk artistic circles, but not only that.

Firstly, the very name of the "Novaya Sibir" society (1926-1931) expressed the idea of uniqueness and selfcontainment of the regional art. That was the position of the TOLKh members and the Krasnoyarsk artists headed by D. I. Karatanov. Secondly, those organizations actively stood for the local art education, they opened drawing classes in Krasnoyarsk and Tomsk in 1910; the problem also was one of the most important for the "Novaya Sibir". Thirdly, the societies under consideration consolidated the art forces and denied the art dictate: TOLKh organized All-Siberian exhibitions involving the metropolitan artists, representing various schools and trends; Krasnoyarsk artists cooperated with foreign artists, war prisoners; the "Novaya Sibir" members understood freedom of self-expression as the most important condition of art existence. Though the Siberian art societies did not manage to prevent separatism of the regional art forces because of different reasons, thanks to their work the artists gained their hopes for professional future and social demand; they activated their supporters and opponents; they helped the artists survive morally, physically, mentally and psychologically in the most difficult years of Russian history.

\section{REFERENCES}

[1] N. M. Yadrintsev. Siberia as a Colony Geographically, Ethnographically and Historically, Novosibirsk, Sibirsky Khronograf (Siberian Chronograph), 2003, p. 468.

[2] A. V. Adrianov. The Drawing School in Tomsk // Sibirskaya Zhizn (Siberian Life), 1913, (No. 283) December 25, p. 3.

[3] Urbanus. Siberian Style or Ornament? // Sibirskaya Zhizn (Siberian Life), 1912, (No. 4) January 5, p. 2.

[4] P. D. Muratov. Siberian Art Life in the 1920s. Leningrad, Khudozhnik RSFSR, 1974, p. 6.

[5] Ibid, p 5.

[6] The Krasnoyarsk Territory Local History Museum Archive (KTLHMA) O/\$ 12020/Д 9709. Р. 89.

[7] Ibid, p. 105.

[8] The Krasnoyarsk Territory State Archive (KTSA). Fond 595. Inventory 3. File 317. Paper 1.

[9] V. F. Chirkov.Siberian Visual Arts in the 17th-20th Centuries: a Glossary in Two Volumes, vol. 2, Tobolsk, AzBuka, 2014, p. 1529.

[10] KTSA. Fond 595. Inv. 52. F. 642. P. 2.

[11] The First Siberian Itinerary Picture Exhibition // Sibirskaya Shkola (Siberian School), 1916, No. 5, p. 86.

[12] KTSA. Fond 42. Inv. 1. F. 2860. P. 1.

[13] KTSA. Fond 42. Inv. 1. F. 2860. P. 12.

[14] KTSA. Fond 161. Inv. 1. F. 160. P. 210.

[15] KTSA. Fond 161. Inv. 1. F. 160. P. 212

[16] The Chronicle. An Itinerary Exhibition // YeniseiskyVestnik (The Yenisei Herald), 1919, April 9 (No. 68), p. 4.

[17] Attention to the Members of the Yenisei Union of Artists and Applied Art Workers // YeniseiskyVestnik (The Yenisei Herald), 1919, December 30 (No. 264), p. 4.

[18] N. V. Lisovsky. The Siberian Artist D. I. Karatanov, Krasnoyarsk, Krasnoyarskoyeknizhnoyeizdatelstvo (Krasnoyarsk book publishers), 1974, p. 120

[19] КTLHMA. О/Ф 95442/Д 2702. Р. 141.

[20] The First Siberian Congress of Artists // SibirskiyeOgni (Siberian Lights), 1927, No. 3, p. 216.

[21] KTSA. Fond P-51. Inv. 1. F. 1005. P. 1.

[22] KTSA. Fond P-51. Inv. 3. F. 44. P. 53.

[23] D. Ya.Severyukhin, O. L. Leikind. The Golden Age of Art Unions in Russia and USSR (1820-1932), SPb, IzdatelstvoChernysheva (Chernyshev Publishing House), 1992, p. 57.

[24] KTSA. Fond P-2120. Inv. 1. F. 355. P. 1.

[25] In the "Novaya Sibir" Artists' Society // SibirskiyeOgni (Siberian Lights), 1926, No. 5-6, p. 260.

[26] Ye. I. Darius. The Artist V. V. Panovsky'sActivity within the Framework of the Barnaul Branch of the "Novaya Sibir" All-Siberian Artists' Society // The Materials of Volgograd State Pedagogical University, 2014, No. 3, p. 86.

[27] L. I. Shapovalova. With Surikov's Message - Andrei Shestakov, Krasnoyarsk, Izdatelsky Dom "KlassPlyus" ("Class Plus" PH), 2015, p. 92. 
[28] The Chronicle // SibirskiyeOgni (Siberian Lights), 1927, No. 3, p. 234.

[29] The First Siberian Congress of Artists // SibirskiyeOgni (Siberian Lights), 1927, No. 3, p. 214.

[30] The First Siberian Congress of Artists // SibirskiyeOgni (Siberian Lights), 1927, No. 3, p. 209.

[31] Zh. Ye. Levina. Art Intellectuals of West Siberia (late 1920-1930s): the author's abstract ... DSc (History). Saint Petersburg, 2007, p. 289.

[32] The First Siberian Congress of Artists // SibirskiyeOgni (Siberian Lights), 1927, No. 3, p. 212.

[33] The Chronicle. Among the Novosibirsk Artists // SibirskiyeOgni (Siberian Lights), 1931, No. 7-8, p. 128. 